7. Reprod. Fert. (1975) 43, 209-219

\title{
ABO BLOOD GROUPS AND HUMAN SEX RATIO AT BIRTH
}

\author{
T. M. ALLAN \\ Blood Transfusion Centre, Royal Infirmary, Aberdeen AB9 2ZW
}

(Received 11th Fuly 1974)

\begin{abstract}
Summary. In the aggregate of the seventeen published series of the $\mathrm{ABO}$ blood groups of newborn babies and their mothers (an aggregate totalling 53,679 mother-baby combinations) there are substantial reciprocal differences by maternal $\mathrm{ABO}$ blood group in respect of the ratio of male to female babies. The ratio is relatively low for $A B$ babies of $\mathrm{AB}$ mothers plus $\mathrm{A}$ babies of $\mathrm{A}$ mothers, but is relatively high for non- $A B$ babies of $A B$ mothers plus non- $A$ babies of $A$ mothers. By contrast, the ratio is relatively high for $\mathrm{O}$ babies of $\mathrm{O}$ mothers plus $\mathrm{B}$ babies of $B$ mothers, but (except in the aggregate of seven of the seventeen series, totalling 16,601 cases) is relatively low for non-O babies of $O$ mothers plus non-B babies of B mothers. Disregarding the babies' blood groups, the sex ratio is higher for babies of $A B$ than of non- $A B$ mothers. Disregarding the mothers' blood groups, the sex ratio is lower for A than non-A babies, while in the author's own series, included above, the ratio is lower for $\mathrm{A}$ babies possessing than for those not possessing detectable $A_{1}$ antigen. It is suggested that a possible cause of these differences is sex-differential fetal mortality caused by interaction of the $A B O$ genes, and some of the sex-determining genes, with oestrogen and progesterone.
\end{abstract}

\section{INTRODUCTION}

In 1925 Hirszfeld \& Zborowski reported a series of 264 mother-baby combinations. They pointed out that the ratio of male to female babies was very much higher for the babies of group $A B$ mothers than for the rest, and they declared that "if this finding were confirmed, it would have far-reaching theoretical significance". Unfortunately, their finding fell immediately into oblivion, but, a third of a century later, it was found to be confirmed (Allan, 1959) in the aggregate, totalling 32,046 cases, of all other series reported between 1924 and 1959 (Dossena, 1924; Badino, 1927; Klaften, 1927; Graff \& Werkgartner, 1928; Kirwan-Taylor, 1930; Goroncy, 1930; Haselhorst, 1930; Hurst, Taylor \& Wiener, 1946; Sanghvi, 1951; Johnstone, 1954; Cohen \& Glass, 1956, 1959; Shield, Kirk \& Jakobowicz, 1958; Allan, 1959).

Meanwhile, Sanghvi (1951) had pointed out that, in his own series, the sex ratio was very much higher for $O$ babies of $O$ mothers and, separately, $B$ babies of $B$ mothers, than for $A$ babies of $A$ mothers. This finding too was found 
to be confirmed in the aggregate of the other 1924-59 series (Allan, 1959), and there the matter rested for a decade. Since 1970, however, three more series have been reported (Krauss \& Zimmermann, 1970; Maráz, Keserü, Kaiser, Annus \& Szontágh, 1972; Golovachen \& Slozina, 1972), while the author's own series has been substantially enlarged. The resulting new aggregate, totalling 53,679 cases, not only provides overwhelming confirmation of the findings both of Hirszfeld \& Zborowski (1925) and of Sanghvi (1951), as is self-evident from the Tables, but has also produced a third finding, complementary to that of Sanghvi, and it is principally this that is dealt with below.

\section{MATERIALS AND METHODS}

The author's series consists of 8074 babies born in 1956-59, mostly to Rhpositive mothers, in Aberdeen Maternity Hospital and its associated nursing homes, and 6377 babies born there in 1960-68 to Rh-negative mothers or to Rh-positive mothers with a history of blood transfusion or stillbirth, or of having had a baby with neonatal anaemia or jaundice, including haemolytic disease of the newborn. As in all the other series, stillborn babies and twins were omitted.

The ABO and $\mathrm{Rh}$ blood groups of the mothers and babies were determined by standard methods, more than once in the case of $\mathrm{Rh}$-negative mothers and of a substantial minority of Rh-positive mothers. Mothers and babies were recorded as $\mathrm{Rh}$-negative if they lacked the antigen $\mathrm{D}$, whether or not they possessed C or E. The sub-groups of a total of 1338 group A babies were determined with absorbed anti- $\mathrm{A}_{1}$ serum.

\section{RESULTS}

Table 1 gives the data from the author's Aberdeen series. It shows, firstly, that in this series there were substantial differences in sex ratio, by maternal ABO blood group, not only between babies of the same group as their mothers but also between babies of a different group from their mothers. Secondly, it shows that the latter differences were reciprocal to the former. Thus the sex ratio was, as expected, higher for $O$ babies of $O$ mothers, i.e. 1.08 (2713:2508), and for B babies of B mothers, i.e. 1.10 (377:344), than for A babies of A mothers, i.e. 1.00 (1571:1567), $\chi^{2}$ being $2.75(P>0.05)$ for the O:A comparison, and $1.07(P>0.30)$ for the B:A comparison. Conversely, the sex ratio was higher for non-A babies of A mothers, i.e. 1-11 (1030:930), than for non-O babies of $O$ mothers, i.e. 1.02 (1060:1042), and for non-B babies of $B$ mothers, i.e. 0.99 (433:437), $\chi^{2}$ being $1.75(P>0.10)$ for the $\mathrm{A}: \mathrm{O}$ comparison, and 1.76 $(P>0 \cdot 10)$ for the A:B comparison.

Table 1 also shows that babies of $A B$ mothers followed the same trend as babies of $A$ mothers, in respect both of babies of the same group as their mothers and of babies of a different group from their mothers. The data were therefore divided into those concerning the babies of $\mathrm{AB}$ plus $\mathrm{A}$ mothers, and those for the babies of $O$ plus $B$ mothers. 


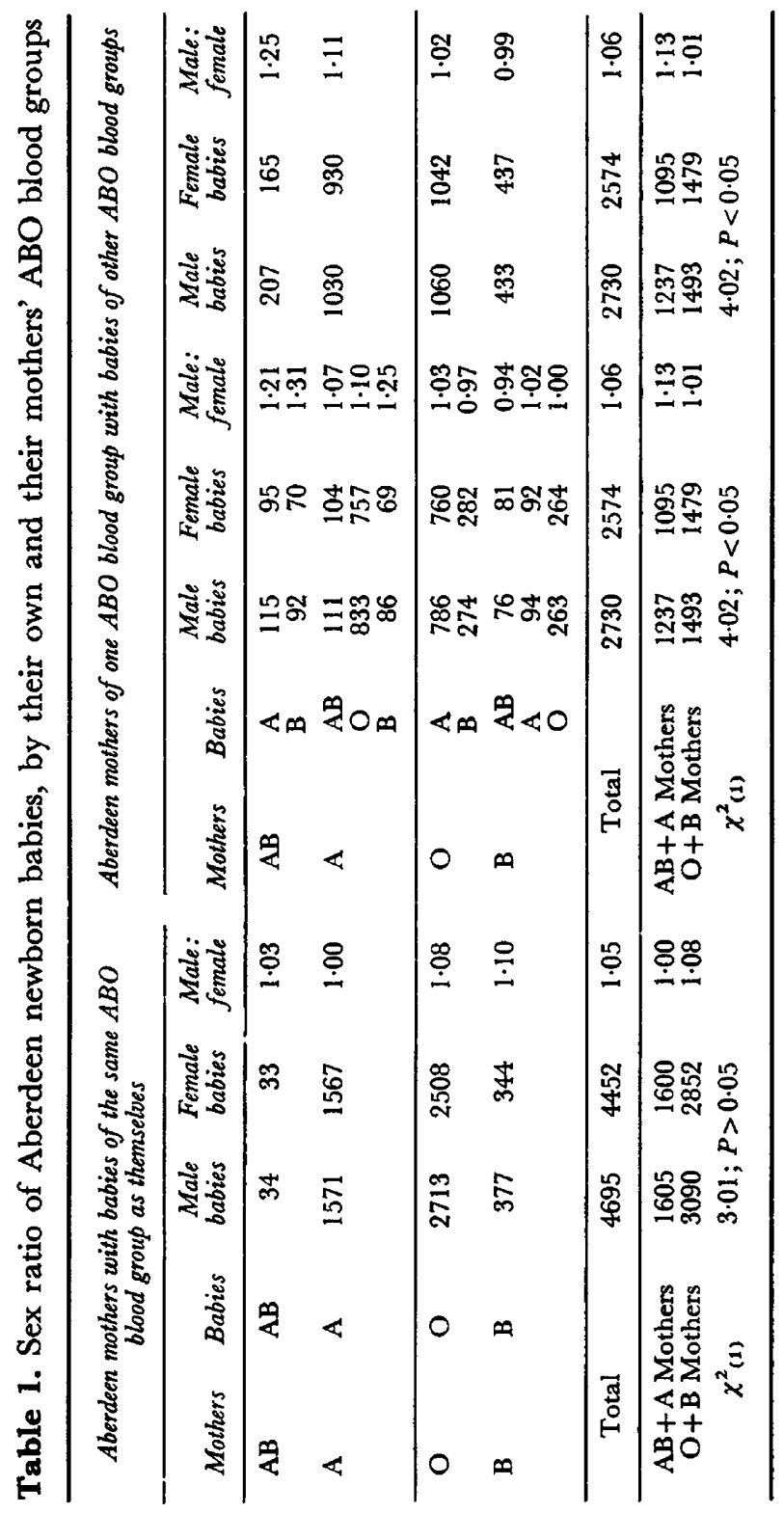


Table 2 compares the author's series with the aggregate of the other sixteen series reported in 1924-74, and shows that the Aberdeen results were paralleled in the sixteen-series aggregate. The sex ratio of non- $A B$ babies of $A B$ mothers plus non-A babies of A mothers was high, both in the Aberdeen series, i.e. $1 \cdot 13$ (1237:1095), and in the aggregate, i.e. 1.15 (4146:3596). By contrast, the sex ratio of non-O babies of $O$ mothers plus non- $B$ babies of $B$ mothers was low, both in the Aberdeen series, i.e. 1.01 (1493:1479), and in the aggregate, i.e. $1.05(4523: 4316), \chi^{2}$ being $4.02(P<0.05)$ in respect of the Aberdeen series and $9.28(P<0.005)$ in respect of the aggregate.

In consequence of the immediately foregoing differences being reciprocal to those observed in respect of babies of the same group as their mother, the sex ratio in the aggregate of all seventeen series reported in 1924-74 was higher for $\mathrm{O}$ babies of $\mathrm{O}$ mothers plus $\mathrm{B}$ babies of $\mathrm{B}$ mothers, i.e. $1 \cdot 11$ (9832:8819), than for non-O babies of $O$ mothers plus non- $B$ babies of $B$ mothers, i.e. 1.04 (6016:5795), $\chi^{2}{ }_{(1)}$ being $9 \cdot 11$, and $P<0 \cdot 005$. Similarly, the sex ratio was higher for non- $A B$ babies of $A B$ mothers plus non- $A$ babies of $A$ mothers, i.e. 1.15 (5383:4691), than for $\mathrm{AB}$ babies of $\mathrm{AB}$ mothers plus $\mathrm{A}$ babies of $\mathrm{A}$ mothers, i.e. 1.01 (6596:6547), $\chi_{(1)}^{2}$ being 23.96, and $P<0.0001$.

By contrast, combination of the above categories of baby shows that, in the aggregate of all seventeen series, the sex ratio was almost exactly the same for the total number of babies of $\mathrm{AB}$ plus $\mathrm{A}$ mothers, i.e. 1.07 (11979:11238), as for the total number of babies of O plus B mothers, i.e. 1.08 (15848:14614). It also shows that the ratio was almost exactly the same for the total number of babies of the same group as their mothers, i.e. 1.07 (16428:15366), as for the total number of babies of a different group from their mothers, i.e. 1.09 (11399: 10486).

The above account requires one substantial qualification, in that the relatively low sex ratio of non-O babies of $O$ mothers plus non- $\mathrm{B}$ babies of $\mathrm{B}$ mothers found in the aggregate of all seventeen series, i.e. 1.04 (6016:5795), was not true of the aggregate of seven of the seventeen series, totalling 16,601 cases (Table 3 ). On the contrary, the sex ratio of such babies in this sub-aggregate was 1.13 (2227: 1972), which was as high as that of non- $A B$ babies of $A B$ mothers plus non-A babies of $A$ mothers in the same sub-aggregate, i.e. $1 \cdot 12$ (1875:1680). For the rest, however, the two sub-aggregates followed the same trend (Table $3)$.

The difference between these sub-aggregates can be considered from the standpoint not only of mothers but also of babies. Thus, in respect of babies of a different group from their mother (babies for whom the overall sex ratio was 1.07 in both sub-aggregates), the ratio was higher for $A B$ plus $B$ babies in the sub-aggregate of the ten series, i.e. $1 \cdot 13(1817: 1615)$ than in that of the seven series, i.e. 1.06 (1226:1155), $\chi_{(1)}^{2}$ being 1.13 , and $P>0.20$. By contrast, the sex ratio was higher for $O$ plus $A$ babies in the sub-aggregate of the seven series, i.e. $1 \cdot 15(2876: 2497)$, than in that of the ten series, i.e. $1.05(5480: 5219)$, $\chi^{2}{ }_{(1)}$ being 7.54 , and $P<0.01$.

In the aggregate of all seventeen series the sex ratio was lower for the total number of A babies, i.e. 1.03 (10476:10141), than for the total number of non-A babies, i.e. $1 \cdot 10(17351: 15711), \chi_{(1)}^{2}$ being $6 \cdot 61$, and $P<0 \cdot 02$. This low 
sex ratio for $A$ babies in general was not, however, characteristic of all four classes of $\mathrm{A}$ baby: on the contrary, the ratio was higher for $\mathrm{A}$ babies of $\mathrm{AB}$ mothers, i.e. 1.31 (618:471), than for $A$ babies of non- $A B$ mothers, i.e. 1.02 (9858:9670), $\chi^{2}{ }_{(1)}$ being 15.96, and $P<0.0001$.

Of the $5080 \mathrm{~A}$ babies in the Aberdeen series, the sub-groups of 1338 were determined. The $A_{1}$ antigen was detected in $333(24.9 \%)$ of these, i.e. in about a third of the percentage of cases in which it was found in Aberdeen schoolchildren (T. M. Allan, unpublished observations). The sex ratio was lower for these 333 babies, i.e. $0.83(151: 182)$, than for the rest, i.e. $1.08(523: 483)$, $\chi_{(1)}^{2}$ being $4 \cdot 15$, and $P<0.05$.

Table 2. Sex ratio of Aberdeen and other white newborn babies, by their own and their mothers' $\mathrm{ABO}$ blood group

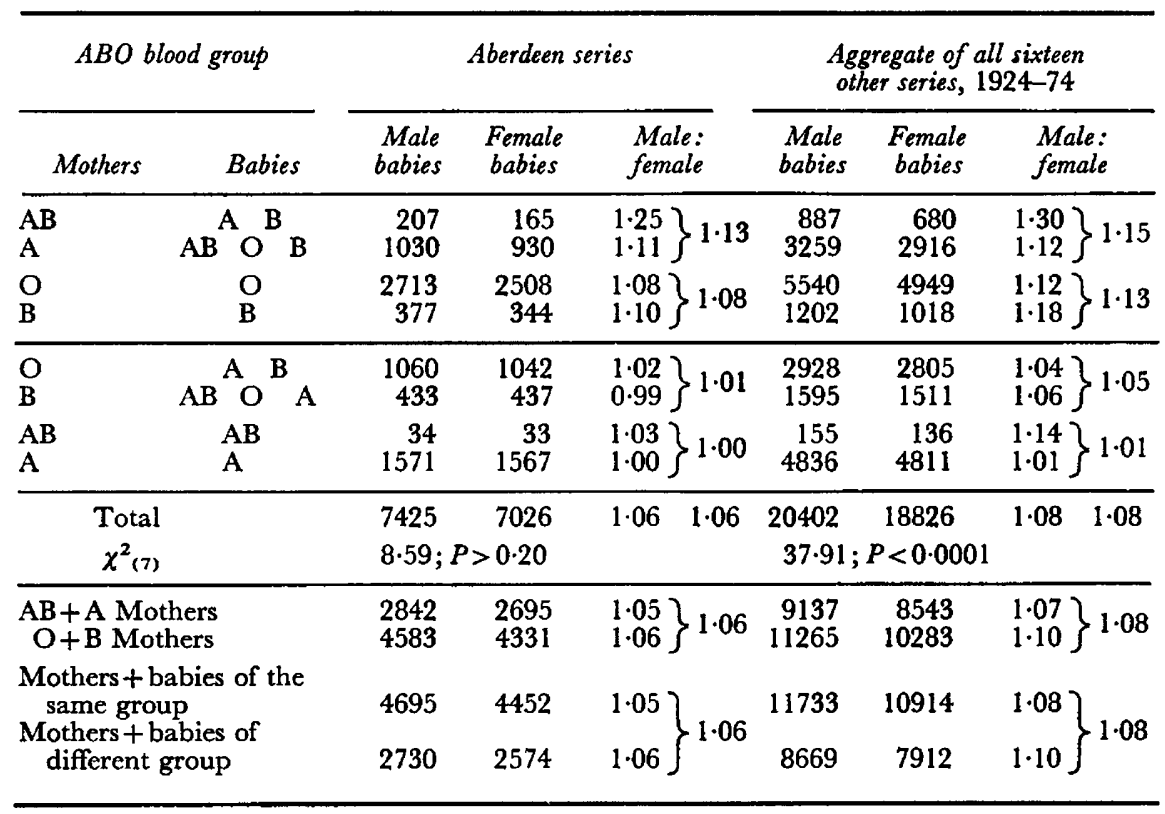

\section{DISCUSSION}

The aggregate data presented above make it virtually certain that there are differences in the ratio of male to female newborn babies in relation to $A B O$ blood group. In respect of individual blood groups, the two most notable differences are, firstly, a higher sex ratio for babies of $A B$ mothers (1.27) than for the rest (1.07), and, secondly, a lower sex ratio for A babies (1.03) than for the rest $(1 \cdot 10)$. These two differences, however, fall within an apparently systematic framework of differences involving mothers and babies of all four groups, in two reciprocal combinations. Thus babies born to mothers of blood groups $\mathrm{AB}$ and $\mathrm{A}$ combined, i.e. babies born to mothers who possess at least one $A$ gene, A individuals being of the genotype $A A$ or $A O$, have, in this aggregate, a relatively high sex ratio $(1 \cdot 15)$ when of a different group from their mothers, 
and a relatively low sex ratio (1.01) when of the same group as their mothers. Conversely, babies born to mothers of blood groups $\mathrm{O}$ and $\mathrm{B}$ combined, i.e. babies born to mothers who lack the $A$ gene, have, in this aggregate, a relatively high sex ratio $(1 \cdot 11)$ when of the same group as their mothers, and a relatively low sex ratio (1.04) when of a different group from their mothers. This reciprocity is such that, when the data for the two types of baby contrasted above are combined, the sex ratio is found to be almost exactly the same for babies of the total number of $\mathrm{AB}$ plus $\mathrm{A}$ mothers (1.07) as for babies of the total number of $O$ plus $B$ mothers (1.08), and almost exactly the same for the total number of babies of the same group as their mothers (1.07) as for the total number of babies of a different group from their mothers (1.09).

This reciprocity recalls the theory of Ford (1942), endorsed by Huxley (1955), that the $A B O$ blood-group genes are an example of balanced polymorphism, i.e. of a genetic system maintained by means of a balance between opposed selective forces, these being themselves nearly always genetic. More particularly, it recalls the model of Owen (1953), consisting of "a genetical system admitting of two distinct stable equilibria under natural selection". Models appropriate to the more complicated balance described above would, however, be far more complex (W. F. Bodmer, personal communication). Moreover to this complexity must be added the complicating factor of the high sex ratio for non-O babies of $O$ mothers plus non- $B$ babies of $B$ mothers found in the aggregate of seven of the seventeen series. This variation may be due to chance, may be a characteristic of the particular populations represented in the seven series concerned, or may be a result of the samples differing in, for example, the proportions of primiparae and multiparae, or the proportions of mothers included more than once.

The data appear to provide no clue as to the particular form which genetic forces, balanced or otherwise, might take in the present context, there being no evidence that the differences found are related to $A B O$ compatibility and incompatibility, to $\mathrm{ABO}$ homozygosity and heterozygosity, or, with the possible exception of A mothers of A babies, to whether the mother is Rh-positive or Rh-negative (T. M. Allan, unpublished observations). Consideration will therefore be given to two theoretical possibilities.

The first of these, suggested by E. B. Ford (personal communication), is that the differences found are due to sex-differential fertilization, resulting from some form of interaction between the $A B O$ blood-group genes and the genes which determine the relative frequencies of the $\mathrm{X}$ - and $\mathrm{Y}$-bearing gametes. The statement of Cavalli-Sforza \& Bodmer (1971) that gametic selection may act in the opposite direction to zygotic selection is complementary to this suggestion, in that, for example, "a gene whose effect is detrimental to zygotes may be selected for in gametes, and a polymorphism may then result when these two opposing forces balance each other". There is, however, no convincing evidence of haploid spermatic expression of the $A B O$ genes (Race \& Sanger, 1968); and indeed, as Cavalli-Sforza \& Bodmer (1971) point out, the whole problem of proving the existence of prezygotic selection is "unsolved, perhaps even insoluble".

The second possibility, suggested by Allan (1972), is that the differences are 


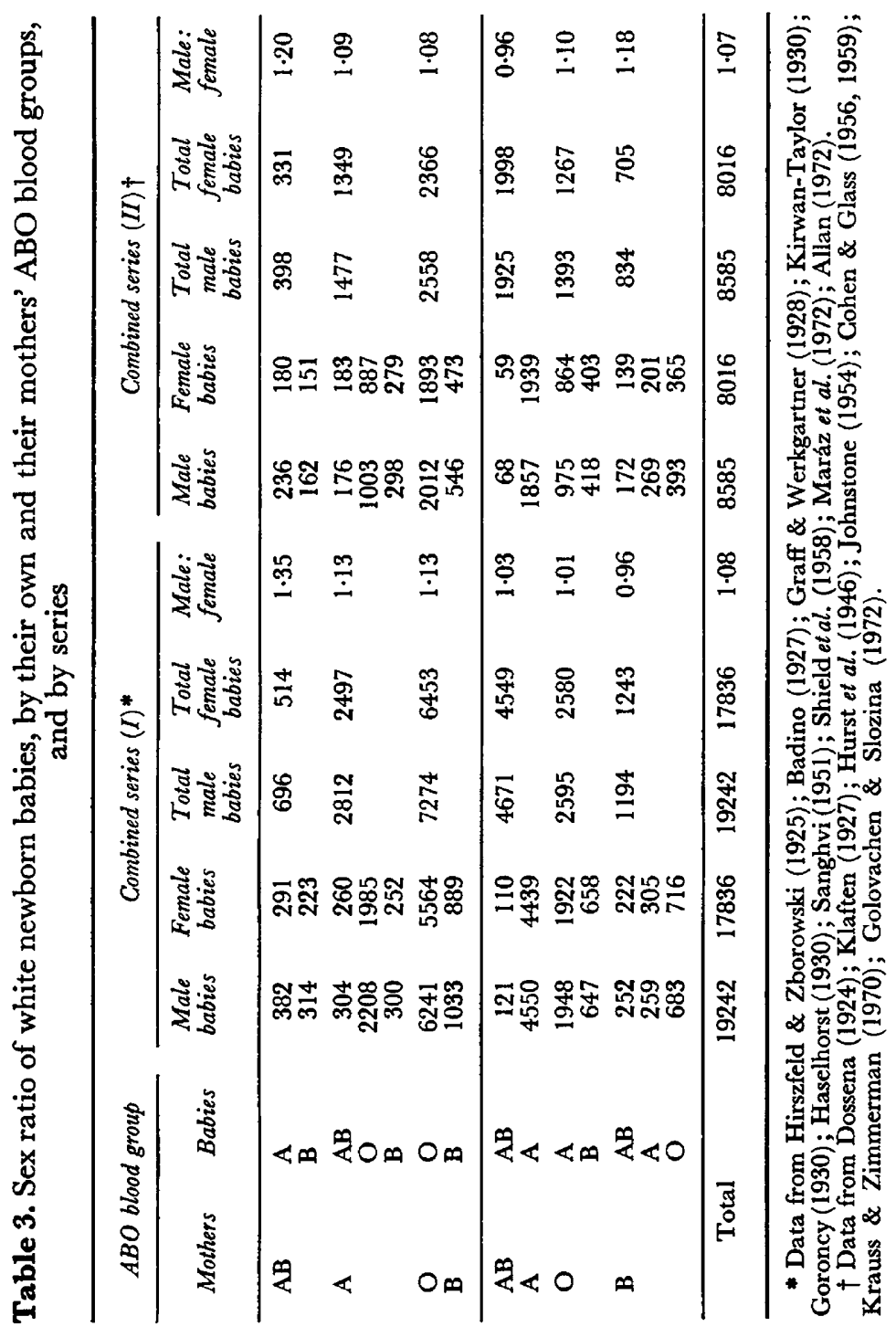


due to sex-differential fetal mortality, resulting from interaction between the $A B O$ blood-group genes and some of the genes determining sex, the interaction being regulated by oestrogen and progesterone, perhaps through a 'threshold dichotomy' (Wright, 1968). This possibility is supported circumstantially by six sets of findings. The first is that one of the precursors of oestrogen and progesterone is cholesterol; that placental biosynthesis of progesterone is affected by fetal sex (Hagemenas \& Kittinger, 1974); and that a slightly raised mean level of serum cholesterol is characteristic of blood-group A (Mayo, Fraser \& Stamatoyannopoulos, 1969). The second is that the association between blood-group A and venous thrombo-embolism (Dick, Schneider, Brockmüller \& Mayer, 1963) is stronger in pregnant or puerperal women than in medical or surgical patients, and is probably even stronger in cases associated with oral contraception (Mourant, Kopeć \& Domaniewska-Sobczak, 1971), in which both oestrogen and progesterone are crucial, and in which the serum cholesterol level is raised (Stokes \& Wynn, 1971). The third is that other conditions associated with blood-group A are superficial puerperal thrombophlebitis (Allan \& Stewart, 1971) and gynaecological cancer (Helmbold, 1961; Garriga \& Ghossein, 1963; Miluničová, Jandová \& Skoda, 1971), including cancer of the breast in middle-aged but not in older women (Hems, 1970), and that, in gynaecological cancer, both oestrogen and progesterone are factors of such importance as to have prompted a blood-group survey of response to therapeutic ovariectomy in cancer of the breast (Lee, 1971). The fourth is that pregnant mice fed on a diet grossly deficient in essential fatty acids (EFA) lose about two thirds of the male fetuses (Rivers \& Crawford, 1974), and that adult male mice have a high EFA requirement which is presumed to be related to the known effects of oestrogen on EFA metabolism (Lyman, 1968). The fifth is that administration of oestrogen and progesterone to rats in the earliest stages of pregnancy markedly raises the sex ratio of live fetuses of nonovariectomized subjects through excess female fetal mortality, and markedly lowers the sex ratio of live fetuses of ovariectomized subjects through excess male fetal mortality, the mean litter size being greatly reduced in both cases (Hahn \& Hayes, 1963). The sixth is that the sex ratio is markedly raised (without effect on litter size) by injection of non-specific anti-oestradiol antibody into rats for the first 4 days after mating (Wotiz, Scublinsky \& Walker, 1972).

The first three of these six sets of findings-those on cholesterol, thromboembolism and gynaecological cancer-suggest that interaction of the $A B O$ genes with oestrogen and progesterone must be considered a possibility, in more than one field, while the finding on EFA in pregnant mice suggests that oestrogen can affect sex ratio indirectly, and the various findings in pregnant rats prove that oestrogen and progesterone can affect sex ratio directly. A possible site of interaction between these hormones and the $A B O$ blood-group genes would be the receptors of the hormones since, if the receptors are glycoproteins, they may have polysaccharide side-chains with either ABO or related specificities (W. F. Bodmer, personal communication), and there is evidence that the oestrogen-receptor association may precede genetic transcription and translation (McGuire \& Lisk, 1971; Hamilton, Teng, Means \& Luck, 1971). 
Other agents which should possibly be considered in this connection are testosterone, HCG, prostaglandins, ACTH and histocompatibility genes. Whatever the mechanisms, however, which may actually be in force, an indication of whether the differences observed are the result of sex-differential fetal mortality or of sex-differential selection at an earlier stage, or both, might well be obtained from large-scale blood grouping and sexing, chromosomal or nuclear, of induced and spontaneous abortuses alike (F. E. Hytten, personal communication). Such studies would have to be performed in the light of the great variety of factors, environmental and genetic, from the prezygotic stage onwards, which are already known to contribute to sex-differential fetal mortality (for references see Geiringer, 1961; Stevenson \& Bobrow, 1967; Hytten \& Leitch, 1971), and also in the light of three complementary sets of evidence on fetal sex ratio in general. The first is the long-standing evidence that in the later stages of pregnancy, there is an excess of male fetal mortality. The second is the accumulating evidence that in the early weeks of pregnancy there is either approximate sex equality in fetal mortality (Tietze, 1948; Bochkov \& Kostrova, 1973) or an excess of female fetal mortality (Mikamo, 1969). The third is the substantial recent evidence (Kaufman, 1973; Fechheimer \& Beatty, 1974) that the mammalian sex ratio at conception is very close to $1 \cdot 00$.

\section{ACKNOWLEDGMENTS}

The blood groups of most of the babies in the author's series were determined as part of a research programme supported by a grant from the Scottish Hospital Endowments Research Trust and the Scottish National Blood Transfusion Association, to both of whom the author is greatly indebted. The new finding was a by-product of a discussion with Dr H. B. M. Lewis, Regional Director of the North-East Scotland Blood Transfusion Service, while the paper owes much to comment at various points by Professor E. B. Ford, Professor W. F. Bodmer, Professor F. E. Hytten, Professor D. F. Kerridge and Professor A. I. Klopper, and by Dr D. R. Abramovitch, Dr K. D. Bagshawe, Dr P. Hull, Dr A. E. Mourant and Dr J. B. Solomon. I am grateful to Professor I. MacGillivray for access to case notes.

\section{REFERENGES}

AlLAN, T. M. (1959) ABO blood groups and sex ratio at birth. Br. med. F. i, 553-554.

AlLAN, T. M. (1972) ABO blood groups and sex ratio at birth. Br. med. F. ii, 528-529.

AlLAN, T. M. \& StEWART, K. S. (1971) ABO blood groups and superficial puerperal thrombophlebitis. Lancet, i, 1125-1125.

Badino, P. (1927) Rapporti sierologice materno-fetale. Rev. Ital. Ginec. 6, 656-664.

Bochkov, N. P. \& Kostrova, A. A. (1973) Sex ratio among human embryos and newborns in a Russian population. Humangenetik, 17, 91-98.

Gavalui-Sforza, L. L. \& Bodmer, W. F. (1971) The Genetics of Human Populations, p. 179. Freeman, San Francisco.

CoHen, B. H. \& GLAss, B. (1956) The ABO blood groups and the sex ratio. Hum. Biol. 28, 20-42.

CoHen, B. H. \& GLAss, B. (1959) Further observations on the ABO blood groups and the sex ratio. Am. F. hum. Genet. 11, 274-278.

Dick, W., Schneider, W., Brockmüller, K. \& MaYer, W. (1963) Interrelations of thrombo-embolic diseases and blood-group distribution. Thromb. Diath. haemorrh. 19, 472-474. 
Dossena, G. (1924) Osservazioni sulle modalità della transmissioni ereditaria nei caratteri dei gruppi sanguini. Ann. Ostet. Ginec. 46, 335-343.

Fechreimer, N. S. \& Beatty, R. A. (1974) Chromosomal abnormalities and sex ratio in rabbit blastocysts. 7. Reprod. Fert. 37, 331-341.

Ford, E. B. (1942) Genetics for Medical Students, p. 143 (7th edn, 1973, p. 162). Methuen, London.

Garriga, R. \& Ghossein, N. A. (1963) The ABO blood groups and their relation to the radiation response in carcinoma of the cervix. Cancer, N.Y. 16, 170-172.

Geiringer, E. (1961) Effect of ACTH on sex ratio of the albino rat. Proc. Soc. exp. Biol. Med. 106, 752-754.

Golovachen, G. D. \& Slozina, N. M. (1972) Distribution of blood groups of the ABO system of mothers and newborns. Genetika, Leningrad, 8, 127-132.

Goroncy, G. (1930) Ǔber Blutgruppen bei Mutter und Kind. Z. Geburtsh. Gynäk. 97, 30-38.

Graff, E. \& Werkgartner, A. (1928) Die Vererbung der Gruppeneigenschaften der roten Blutkörperchen. Beitr. gerichtl. Med. 7, 98-123.

Hagemenas, F. G. \& Kittinger, G. W. (1974) The effect of fetal sex on placental biosynthesis of progesterone. Endocrinology, 94, 922-924.

HAHN, E. W. \& HAYs, R. L. (1963) Modification of the secondary sex ratio in the albino rat by progesterone and oestrogen therapy. 7. Reprod. Fert. 6, 409-411.

Hammton, T. H., Teng, C-S., Means, A. R. \& Luck, D. N. (1971) Estrogen regulation of genetic transcription and translation in the uterus. In The Sex Steroids : Molecular Mechanisms, pp. 197-241. Ed. K. W. McKerns. Appleton-Gentury-Grofts, New York.

Haselhorst, G. (1930) Blutgruppenuntersuchungen bei Mutter und Kind in 2300 Fällen. Z. KonstLehre, 15, 177-204.

Helmbord, W. (1961) Sammelstatistik zur Prüfung auf Korrelationen zwischen dem weiblichen Genitalcarcinom und dem ABO- und Rhesus-system. Acta genet. statist. med. 11, $29-51$.

Hems, G. (1970) Epidemiological characteristics of breast cancer in middle and late age. Br. F. Cancer, 24, 226-234.

Hirszpeld, L. \& Zвorowski, H. (1925) Gruppenspecifische Beziehungen zwischen Mutter und Frucht. Klin. Wschr. 4, 1152-1157.

Hurst, J. G., TAylor, H. C. \& Wiener, A. S. (1946) Individual blood differences in relation to pregnancy. Blood, 1, 234-246.

Huxley, J. S. (1955) Morphism and Evolution (Bateson Lecture). Heredity, Lond. 9, 1-52.

Hytten, F. E. \& Leitch, I. (1971) The Physiology of Human Pregnancy, 2nd edn, p. 469. Blackwell Scientific Publications, Oxford.

Johnstone, J. M. (1954) Sex ratio and the ABO blood group system. Br. F. prev. soc. Med. 8, $124-127$.

Kaufman, M. H. (1973) Analysis of the first cleavage division to determine the sex-ratio and incidence of chromosome anomalies at conception in the mouse. 7. Reprod. Fert. 35, 67-72.

KIRwan-Taylor, G. K. (1930) The inheritance of the blood group factors. F. Path. Bact. 33, 313-326.

Klaften, E. (1927) Uber Hämagglutination und ihre Praktische Bewertung. Z. Geburtsh. Gynäk. 76, 91-107.

Krauss, A. \& Zimmermann B. (1970) Die Vererbung der Blutgruppen A, B, O und Rh. Zentbl. Gynäk. 92, $12-20$.

LeE, Y.-T. N. (1971) The ABO blood groups and results of therapeutic oophorectomy. Surg. Gynec. Obstet. 132, 871-875.

Lyman, R. L. (1968) Endocrine influences on the metabolism of polyunsaturated fatty acids. Progr. Chem. Fats, 9, 193-230.

McGurRe, J. L. \& Lisk, R. D. (1971) Estrogen receptors and their relation to reproductive physiology. In The Sex Steroids: Molecular Mechanisms, pp. 53-73. Ed. K. W. McKerns. Appleton-CenturyGrofts, New York.

Maráz, A., Keserü, T., Kaiser, G., Annus, J. \& Szontágh, F. (1972) Anya és magzatának vércsoportja az újsjülöttek nemi aránya. Orv. Hétil. 113, 901-902.

Mayo, O., Fraser, G. R. \& Stamatoyannopoulos, G. (1969) Genetic influences on serum cholesterol in two Greek villages. Hum Hered. 19, 86-99.

Mгкамо, K. (1969) Female preponderance in the sex ratio during early intrauterine development: a sex chromatin study. Fap. 7. hum. Genet. 13, 272-277.

Mrluničová, A., Jandová, A. \& SKodA, V. (1971) Tumour sensitivity to cytembena in women with metastasizing gynaecological carcinoma, in relation to certain inherited blood characters. Neoplasma, 18, 289-298.

Mourant, A. E., Kopeć, A. G. \& Domaniewska-SobczaK, K. (1971) Blood-groups and blood-clotting. Lancet, i, 223-228.

Owen, A. R. G. (1953) A genetical system admitting of two distinct stable equilibria under natural selection. Heredity, Lond. 7, 97-102. 
RAcE, R. R. \& SANGER, R. (1968) Blood Groups in Man, 5th edn, p. 42. Blackwell Scientific Publications, Oxford.

Rivers, J. P. W. \& CRAWFord, M. A. (1974) Maternal nutrition and the sex ratio at birth. Nature, Lond. 252, 297-298.

SANGHvi, L. D. (1951) ABO blood groups and sex ratio at birth in man. Nature, Lond. 168, 1077-1079.

SHIELD, J. W., KIRK, R. L. \& JAKoBowicz, R. (1958) The ABO blood groups and masculinity of offspring at birth. Am. F. hum. Genet. 10, 154-163.

Stokes, T. \& WYNN, V. (1971) Serum-lipids in women on oral contraceptives. Lancet, ii, 677-681.

Stevenson, A. G. \& Bobrow, M. (1967) Determinants of sex proportions in man. F. med. Genet. 4, 190221.

TIETZE, C. (1948) A note on the sex ratio of abortions. Hum. Biol. 20, 156-160.

Wotiz, H. H., Scublinsky, A. \& Walker, G. (1972) Effect of estrogen antibodies on pregnancy in the rat. Gynec. Invest. 3, 124-125.

Wright, S. (1968) Evolution and the Genetics of Populations, Vol. I, p. 119. Chicago University Press. 